\title{
AURORA DE LA CONCIENCIA POÉTICA
}

Mauricio López Noriega*

\section{Odiseo multiforme preconiza el} advenimiento de un mundo distinto al del guerrero épico: el cosmos aristocrático comienza a resquebrajarse y Eos, la aurora de rosados dedos, cambia de signo al inaugurarse otro tipo de luminosidad, cuyos incipientes reflejos alumbran una utilización diferente de la palabra y de la responsabilidad que implica en diferentes niveles, antropológico, político, ético, estético:

¿Cuál es la desgracia del exilio? 'Una y grandísima', según Polínices: 'no tener libertad de palabra [parrēsía].' Y su madre Yocasta añade: 'Es típico de un siervo no decir lo que piensa.' La franqueza, primer rasgo de la ética aristocrática, se seculariza, con la democracia, en la libertad de palabra (parrēsía). Ulises escapó a una y otra. Negaba la franqueza del guerrero, cuando en Ítaca se fingía loco para no embarcarse hacia Troya; negaba la libertad de palabra, cuando asumía el papel de mendigo vagabundo, que puede ser silenciado y expulsado por cualquier siervo [...] El héroe prefiguraba una condición en la que ni la franqueza aristocrática ni la democrática libertad de palabra resultarían adecuadas. Muchos siglos después, tal condición parece normal, pero en los tiempos de Ulises era una videncia concedida únicamente a quien ha vagabundeado mucho entre el cielo y la tierra. ${ }^{1}$

* Departamento Académico de Estudios Generales, ITAM.

${ }^{1}$ Roberto Calasso, Las bodas de Cadmo y Harmonía, 1990, Barcelona, Anagrama, trad.

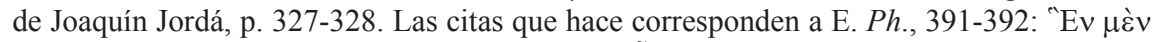

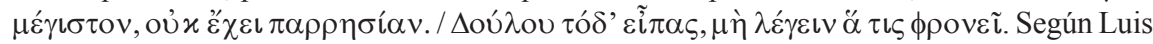
Gil (Censura en el mundo antiguo, 1985, Madrid, Alianza Editorial, p. 48 y nota 65) vertiente 
Pero el viajero Ulises es todavía Homero. El amor que recibe, por ejemplo, ya de Calipso o de Nausícaa, ya de Circe, de Penélope o de la misma Atenea, se mantiene como conciencia diferida, en voz de un magistral narrador, que relata en tercera persona y a quien, finalmente, no pertenecen las posibles consecuencias del amor o del odio, de acciones, hechos y palabras. No por ello Homero deja de ser el más alto poeta, educador de Grecia. Sin embargo, se puede adivinar ya el surgimiento, levísimo, del alba de una primera persona que piensa y siente, y que quiere actuar. Entra en escena por vez primera el yo: este cambio de voz tendrá, en adelante, incontables ecos en la historia de la literatura y del pensamiento, de lo político y lo ético, del odio y del amor.

No es novedad que, mediante su poesía, los líricos griegos arcaicos incidieron con fuerza en la generación de una $\pi \alpha \iota \delta \varepsilon i ́ \alpha$ nueva, como tampoco lo es el conocimiento del riesgo que corrían cuando su actividad se vinculaba con cierto compromiso político.

El contexto en el cual algunos líricos como Safo, Alceo, Anacreonte, Íbico y Píndaro generaron su poesía está ligado de manera estrechísima a la tiranía griega, en particular a los certámenes y simposia, donde se bebía y se escuchaban las composiciones de los poetas: disfrute abierto en una serena balaustrada, ventana luminosa de la sombría existencia que el poeta buscaba alumbrar por medio de su canto. Fueron los líricos griegos quienes por primera vez comenzaron a sentir profundamente la tensión entre la libertad de palabra, es decir, de pensamiento y opinión, y la franqueza aristocrática.

Cuando se habla de libertad de palabra en el mundo griego del siglo VI a. de C. debe entenderse, precisamente, libertad de palabra, no de escritura, pues ésta no existía aún en sentido literario; las inscrip-

subjetiva de la isegoria es la parrhesia “o 'todo decir', ese natural impulso a manifestar con sinceridad absoluta y sin inhibición alguna los juicios personales [...] su traslado a la vida privada suponía para el individuo la posibilidad de desarrollar sin trabas su personalidad por los cauces elegidos, juntamente con el derecho cultural de legar a sus conciudadanos el mensaje de su sentir y su pensar". Sin embargo, esto sería realidad en la Atenas del siglo V a. de C. y no necesariamente bajo las tiranías previas. 
ciones en tumbas, los epitafios no pueden ser considerados literatura propiamente dicha. ${ }^{2}$ La distancia que nos separa de la Grecia arcaica no es solamente temporal: es un abismo entre dos formas de concebir el mundo, al yo dentro de ese mundo y a los dioses en relación con el mundo y con la conciencia de la persona ${ }^{3}$ como sujeto actuante, activo, inserto en una determinada sociedad, frágil aún, en especial en el contexto del siglo VI a. de C. Vale la pena un punto de comparación que muestre cuán alejados de esta forma de conciencia vivimos, cuán diferente es la pregunta o dato inicial:

Empecemos con uno de esos hechos [fundamentales]. En concreto, con el que se halla en la base de todo: el hecho de que yo existo, de que yo he nacido [...] Esto significa que, para mí, yo mismo soy algo dado. Que soy, sencillamente, lo dado, lo obvio; aquello a lo que todo lo demás se refiere, y desde lo que yo me enfrento con todo lo demás. Yo me presupongo en todo. Cualquier cosa que digo contiene, de forma explícita o implícita, la palabra 'yo' [...] Cualquier acto que realizo es realizado por 'mí' [...] Así pues, yo soy el otro polo vivo del mundo. Para mí el mundo sólo existe como aquel en el que yo estoy, que me

2 "What is now generally considered lyric-a short poem of personal revelation, confession or complaint, which projects the image of an individual and highly self reflexive subjective consciousness- is only possible in a culture of writing", Paul Allen Miller, Lyric text and lyric consciousness: the birth of a genre from archaic Greece to Augustan Rome, 1994, London, Routledge, p. 1 ( $v$. también las referencias).

${ }^{3}$ La utilización del término 'persona', como concepto, sería imposible en el contexto de la Grecia arcaica; lo utilizo haciendo énfasis en lo anterior, y en la forma en que Boecio (Tratados teológicos y La consolación por la filosofía, 1989, México, Consejo Nacional para la Cultura y las Artes, col. Cien del mundo, trad. de los Tratados de Carlos Montemayor) define 'persona' en su tratado Contra Eutiquio y Nestorio, III, 5-6: "la substancia individual de una naturaleza racional”; más adelante explica de dónde procede dicho término: "La palabra persona viene de otra parte, evidentemente de las máscaras o personas con las que se representaban todos los personajes de las comedias y tragedias. Persona, en latín, deriva, con acento circunflejo en la penúltima sílaba, de personando, que significa resonando. Pero si la acentuamos en la penúltima, se ve clarísimo que proviene de sonus, que es sonido; y es de sonus porque la concavidad de esta máscara hacía más grande el sonido. Los griegos llamaban también a estas máscaras o 'personas', $\pi \rho o ́ \sigma \omega \pi \alpha$, porque ellas se ponían sobre

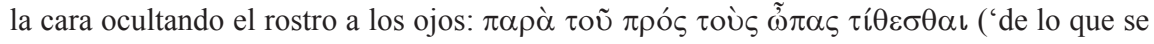
colocaba contra el rostro')", III, 8-17. 
sale al encuentro, que yo capto y siento, en el que yo actúo. En sentido propio, 'mundo' es aquel que se da entre los polos de mi yo y del universo formado por todo lo que no soy yo. ${ }^{4}$

El dato original de la existencia no era algo obvio para el hombre de la Grecia arcaica; son dos concepciones enteramente alejadas, dos figuras de vida diferentes de manera sustancial: entonces apenas se levantaba la aurora del yo griego. No fue únicamente una diferencia entre géneros, entre épica y lírica; ${ }^{5}$ la conciencia inividual apenas se encontraba en proceso de inicio y configuración. Se trata aquí de un fenómeno también comunicativo que se encontraba en proceso de ser, que estaba deviniendo: de los rapsodas y aedos que recitaban las gestas homéricas, ya más o menos fijas en la atmósfera general de los grupos sociales, a la existencia de un poeta como tal, creador y con plena conciencia de su creación; entre Homero y los líricos se pasa por un entreacto llamado Hesíodo, eslabón entre la épica y la conciencia

${ }^{4}$ Romano Guardini, Ética. Lecciones en la Universidad de Munich, 2000, Madrid, Biblioteca de Autores Cristianos, trad. de Daniel Romero y Carlos Díaz, p. 394. El autor advierte previamente que esto puede parecer una nimiedad, una banalidad, porque hablar del fenómeno del yo puede suponerse algo muy sencillo, "pero entre las tareas de la filosofía está el reconocer que el lado aparentemente banal de los hechos fundamentales es el reverso de su profundidad y plenitud de sentido", ibid., p. 393.

${ }^{5}$ Para la diferencia entre géneros puede servir un pequeño poema de Anacreonte, el fr. 56: "No es amigo el que, junto a la crátera llena bebiendo vino, / contiendas y guerra lacrimosa narra, / sino quien, de las Musas y de Afrodita los dones espléndidos / mezclando,

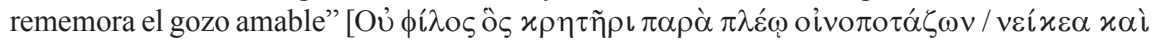

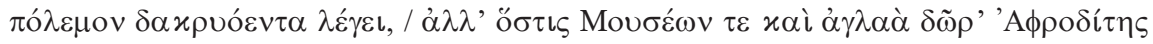

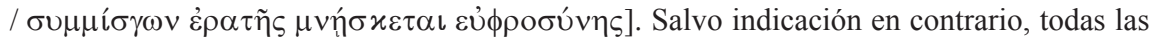
traducciones son mías. Oswin Murray, desde otra óptica, piensa que el cambio entre épica y lírica pasa por el tipo de espacio y auditorio, lo que incide en la conciencia del poeta: "One of the most striking features of the Archaic symposium is of course its function as a place of performance for poetry [...] The advent of the reclining symposium in the mid-eighth century had considerable effect on the self-representation of the poet, and it would be reasonable to connect this with the changing relationship between the poet an his audience [...] Much of what is most characteristic of the themes of monodic lyric belongs to this self-conscious development away from the conceptual world of the Homeric aoidos, in the social context of a symposium which saw itself in conflict with the Homeric model", "War and the Symposium", en William J. Slater, Dinning in a Classical Context, 1991, Ann Arbor, The University of Michigan Press, p. 94-5. 
personal del 'poeta', pues Hesíodo invoca aún la autoridad de las Musas para transmitir un mensaje que su público pueda creer, asimilar y hacer suyo. La lírica griega arcaica es el surgimiento de una forma primaria de subjetividad que comienza a germinar, sin estar todavía separada de la autoridad de los dioses, pero que brota ya con un tono nuevo, diferente, con un matiz en el cual el yo principia por manifestarse como cierto reflejo de la sabiduría y el poder de la divinidad, y que se transmite como una serie de ideas que están latentes en una cultura capaz ya de entenderlas y convertirlas en propias. ${ }^{6}$

Efectivamente, los poemas homéricos inician con una supeditación al poder creador de la palabra divina, que hace del poeta un cáñamo vacío por el cual sopla la autoridad de la voz de la diosa: "La cólera canta, oh diosa, del pélida Aquiles", "Cuéntame, oh Musa, del hombre poliforme"; Hesíodo también se arropa bajo esta potestad: "Comencemos el cantar de las Musas del Helicón"; "Musas de Pieria, que con los cantos otorgaís fama, / ¡vamos!, contad de Zeus”. ${ }^{7}$ En la lírica, aunque

${ }^{6}$ Por ejemplo, en cuanto se refiere al amor y al deseo, se entienden en el poeta lírico ya como independientes del ritual de la comunidad: "Erotic desire is the privileged theme of lyricism, above all because of the organic basis which creates it anew in each individual. Desire as a cultural reality is in the first place a collective and de-individualizing phenomenon because the object of desire is always in one way or another collectively designated, yet it is only the individual who imagines and desires -which is precisely what defines him as individual. The lyric genre is thus the birthplace of a Self which maintains its fragile identity only by finding an ever-new expression for what it lacks", Eric Gans, "The Birth of the Lyric Self: From Feminine to Masculine", Helios, VIII, 1, 1981, p. 35.

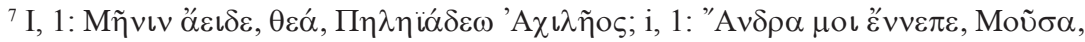

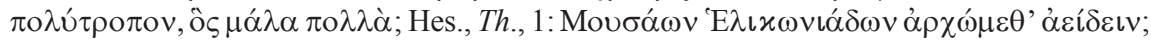

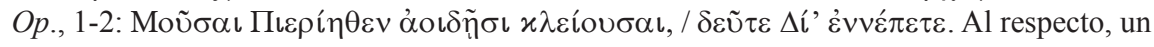
exhaustivo análisis se puede encontrar en Claude Calame, The craft of poetic speech in ancient Greece, 1995, Ithaca, New York, Cornell University Press, p. 35-48, en donde se advierten las particularidades de la enunciación en Homero y en los himnos homéricos, y luego en Hesíodo; más adelante, un capítulo especial se abre para el beocio: "Hesiod: Mastery over Poetic Narration and the Inspiration of the Muses", ibid., p. 58-74, del cual es conveniente consignar la conclusión de Calame: "As I have tried to show [...] Hesiod's $I$ is not always the mere receiver of the honeyed words of the Muse; in certain passages it requires the function attached to its enunciative role of narrator/speaker. This ambiguous situation indicates the intermediary position occupied by Hesiod not only between an oral tradition and a poetry which suggests more and more that is was written down but, more important, between a 
existe todavía esta especie de 'encomendamiento', en el sentido de ponerse bajo la tutela del dios, bajo la protección del imperio de lo sagrado, el hombre sabe, quizá por vez primera, que es él mismo quien habrá de cargar con el peso de la palabra, y la invocación no es sólo para dejarse 'habitar' por el espíritu de la divinidad. ${ }^{8}$

Lo anterior no implica un rompimiento absoluto con la épica, sino un movimiento dialéctico ${ }^{9}$ que enriquece la actividad creativa, presentando dicha acción desde otro enfoque, con mecanismos diferentes y para un auditorio con el cual se comparte la proyección del yo como $\tilde{\eta} \theta$ os común. Un enfoque del problema lo ofrece Gentili:

Bajo el aspecto de la comunicación oral no hay solución de continuidad entre la poesía homérica y la poesía lírica [...] La tendencia homérica a representar emociones y estados de ánimo como un mutuo

society in which the influence of the gods is felt to be predominant and a civic life in which the individual takes on social responsability, the result of which is a growing practical efficiency, even in poetry", ibid, p. 74.

${ }^{8}$ Gans, op., cit., aclara lo anterior: "Lyric poetry can only seem to be an allegorical extension of ritual, an importing of the rethoric of the sacred into the profane world"; enseguida establece una diferencia sustancial ya no sólo en cuanto a la relación entre el hombre y el dios, sino también en un sentido más amplio que incluye una forma de relación con la comunidad: "Contrary to the connection between man and god, the relation of the lyric couple possesses a potential resolution in reciprocity [...] The public's relation to this desired resolution does not pass through collective participation in the desire for divine presence by individual identification with the wordly desire of another individual. This distinction may belong to literature in general, but it is in the lyric genre that is most radical", p. 34-35. En términos de oralidad/escritura, Calame no difiere sustancialmente en sus conclusiones: "The gradual disapearance of the divine guarantee, as represented by the presence of the Muse, is less dependent on the adoption of writing than on the rules of the genres and on the process of profound social change taking place in the Greek city in the archaic period [...] The expansion of the world, which is at the root of the development of the assembly of citizens, center of the civic life of the classic polis, is an oral process; writing plays a secondary role, and we must stop seeing this technical avance as the key to the evolution of archaic Greek society and its literary productions", op. cit., p. 55.

9 "For lyric subjectivity exists not as a linear narrative, nor as a mirror of what physicists call the arrow of time, but rather as an interrelated series of temporal loops moving at various speeds and levels of consciousness. It proceeds not one day at time, but moves forward and back simultaneously, compulsively analyzing and reinterpreting the same multivalent experiences, even as it adds to them", Miller, op. cit., p. 2. 
intercambio personificado entre el héroe y un dios o entre el héroe y uno de sus órganos (thymós, kradie), en una especie de soliloquio entre la persona y una parte de sí misma, opera aún en la lírica arcaica [...] Se trata de una postura mental o, como se le ha definido, de una psicología de la performance poética que mira a hacer público lo personal y subjetivo para hacerlo inmediatamente perceptible e instituir así una relación de emocionalidad con el auditorio. ${ }^{10}$

La idea de la subjetividad, del yo en la lírica griega arcaica, ha ido cambiando significativamente entre los investigadores, en particular durante los últimos cuarenta años. Se había considerado anteriormente, desde fines del siglo XIX, que la poesía lírica griega era el nacimiento puro de la expresión subjetiva, del despertar de la personalidad del individuo fuera ya de los lazos sociales que se le imponían, en ocasiones, de manera violenta; no obstante, esta idea resultó una idealización que paulatinamente se ha ido enriqueciendo con distintas aportaciones; por otro lado, tampoco se puede negar categóricamente que no se hubiera producido este principio de subjetividad e individualidad. Un panorama más amplio indica que el nacimiento del yo no estuvo aislado de su participación en una comunidad; desde la filología, la semiótica, la lingüística, la antropología y la sociología, entre otras disciplinas, se ha llegado a una apreciación más dilatada de la complejidad del fenómeno que entraña el florecimiento de la lírica. ${ }^{11}$ Jaeger,

${ }^{10}$ Bruno Gentili, Poesía y público en la Grecia Antigua, 1996, Barcelona, Quaderns Crema, trad. Xavier Riu, p. 91; en el mismo lugar afirma que, sobre los fenómenos del carácter y la persona humana, concebida como un campo abierto de fuerzas, no como una entidad compacta y cerrada, son válidas aún las observaciones de Fränkel ("Der Charakter in der Sprache der frühgriechischen Dichtung [Homer, Semonides, Pindar]", Am. Journ. Philol., 60, 1939); al respecto, añade Miller: "Lyric as I have defined it is the re-presentation not simply of a 'strong personality', but of a particular mode of being a subject, in which the self exists not as a part of a continuum with the community and its ideological commitments but is folded back against itself, and only from this space of interiority does it relate to 'the world' at large. To borrow the terminology of Bruno Gentili, we might say that the subjectivity presented by the early Greek lyrists is an 'open field of forces"', op. cit., p. 4.

${ }^{11}$ Por ejemplo, en el prólogo al libro citado de Calame, Coquet afirma que "as good philologists, we can (we should) rely on the forms of the language. Grammar is used here 
Snell, Treu, Gundert, Fränkel y otros más inciaron una manera nueva de formular los cuestionamientos en torno a la lírica griega arcaica, en búsqueda de información y respuestas en función de una historia de las ideas y de la mentalidad; así, una de las conclusiones fue que el yo surgió como resultado de una poesía lírica cantada para un auditorio; evidentemente, comenzaron las precisiones en cuanto a lo que significa lírica y a sus diferentes subgéneros (el yambo y la elegía frente a la monodia) y a los distintos tipos de audiencia. ${ }^{12}$ Slings sintetiza las posturas, divergentes entre sí, de dos serios estudiosos, Dover y West, del siguiente modo: "en la hipótesis de West el yo ficticio es un derivado de, y condicionado por, un él/ella ficticio o por un ficticio tú- la visión de Dover no requiere tal condición y es, por ello, mucho menos limitada y mucho más radical". ${ }^{13}$ Otros autores irían contribuyendo desde distintas ópticas; alguna, como la de Rösler, en franca oposición a la de West, frente a quien emplea dos argumentos: por un lado, West niega el valor del auditorio; por el otro, el problema de la oralidad apunta a la imposibilidad de un yo ficticio que narrara una historia artificial en una sociedad en la cual la poesía es cantada y escuchada, no leída y escrita. Se llegó, finalmente, a extremos como el de Bremer, 14 quien sostiene que el yo es la máscara del poeta; si éste es quien debe entretener a un auditorio, no tenemos el derecho a quitarle su máscara y buscar una verdad escondida y autobiográfica, porque el poeta no aspira a decir la verdad; de hecho, incluso plantear esta pregunta sería

less to analyze discourse than to register the conditions under which it is formulated or, more important, altered and, finally, to discover who takes the responsability for it", p. xv; por su parte, Gans enfatiza el hecho de que el análisis no debe ser sólo sociológico o antropológico y ofrece un ejemplo de interpretación casi de género: "On the sociological plane the 'mystifying' strope [sic] of Anacreon has therefore a richer future than the 'sincere' one of Sappho. If femenine poetry has greater anthropological profundity, it lacks the possibility granted to the male poets of drawing its images from the resources of social life", op. cit., p. 47.

${ }^{12}$ Cfr. S. R. Slings, "The 'I' in personal Archaic Lyric: an Introduction”, en Slings (ed.), The Poet's I in Archaic Greek, Proceedings of a Symposium Held at the Vrije Universiteit Amsterdam, 1990, Amsterdam, Vrije Uruversiteit, p. 1-3. El célebre libro que Slings toma como punto de partida es el de Fränkel, Dichtung und Philosophie des frühen Griechentums (Nueva York, 1951), en especial el índice A "Das 'ich' in der Lyrik".

${ }^{13}$ Slings, ibid., p. 7. 
malentender la naturaleza de la poesía lírica. ${ }^{14}$ Este breve recorrido me parece oportuno y necesario para destacar la propia postura de Slings, que encuentro atractiva, de tal manera que pueda exponer la mía. Este autor sostiene que no es tan importante si el poema lírico fue o no transmitido oralmente, sino si lo fue hecho como una performance y no (o marginalmente) para ser leído; además, argumenta que precisamente si se trata de una poesía de transmisión oral, entonces cabe suponer que el poeta es el causante de una experiencia estética y, por tanto, en cierto modo se despersonaliza:

El Yo es el Yo del ejecutante, quien se mueve a través de un continuum, en el cual el Yo biográfico y el Yo ficticio son dos extremos: la mayor parte del tiempo no es ninguno [...] El problema del Yo es nuestro problema, y sólo podemos resolverlo convirtiéndonos en parte de la audiencia. ${ }^{15}$

Un poeta puede decir que las Musas lo impelen a cantar, o que está enamorado, o expresar una opinión porque busca que su audiencia lleve a cabo una acción determinada -pensemos, por ejemplo, en el ámbito de la política; inclusive, el poeta puede narrar algo que (supuestamente) hizo, como por ejemplo, un viaje. Este poeta puede decir las mismas cosas de diferente forma, es decir, utilizando un género determinado para un auditorio definido, lo cual no impide que los subgéneros se traslapen y las ideas se puedan llegar a confundir en el formato. La cuestión, en definitiva, sería preguntarse: ¿qué tipo de yo es el que, según la interpretación que se le dé, puede lograr la mejor elucidación del poema? ¿Ficcional, representativo (performativo), biográfico? Luego de una larga ejemplificación, Slings llega a su conclusión final que me parece sincera: "en las tres últimas décadas, se han hecho muchas aseveraciones generales acerca del Yo en la lírica

${ }^{14}$ Ibid., p. 9, lo cual entraría en contradicción con la postura, que prefiero, de Marcel Detienne (Los maestros de verdad en la Grecia arcaica, 1981, Madrid, Taurus, trad. de Juan José Herrera) quien entiende al poeta lírico como un maestro de Verdad; en particular, v. p. 21-38.

${ }^{15}$ Slings, op. cit., p. 12 [...] 16. 
arcaica; he seguido aquí el que me parece el único camino correcto: comenzar por leer e interpretar los textos". ${ }^{16}$ Ya lo había adelantado al decir que el lector debe convertirse en parte de la audiencia; esta solución concluye tomando en cuenta tanto el contexto general como una idea particular suya que debe ser destacada:

Los poetas líricos griegos trataron desesperadamente de hacerse iguales a sus colegas épicos, y lo lograron. Pero la ingenuidad y espontaneidad de la poesía lírica perdió algo en el proceso. Al intentar sustituir las reivindicaciones de veracidad y conocimiento de los poetas épicos; al volverse sus poemas cada vez más del dominio público, dirigidos a la comunidad considerada un todo, de la cual se erigieron como una nueva clase de maestros, el Yo personal se desvaneció. Cuando todo está dicho y hecho, la historia del Yo en la lírica griega se vuelve un proceso de despersonalización. ${ }^{17}$

Estoy de acuerdo con varios de los argumentos de Slings aunque no con la conclusión final (¿qué significará, por ejemplo, "cuando todo está dicho y hecho", si apenas comenzaban a hincarse los cimientos

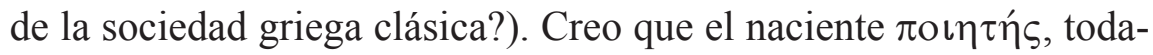
vía $\rho \alpha \psi \omega \delta$ ós, $\alpha \circ$ ot ós aún, si bien toma lo necesario de la tradición épica, busca transformarlo desde un contexto (tiempo, espacio, persona) y una reflexión personal, para integrarlo (transmitirlo, reflejarlo, devolverlo) a la comunidad a la que pertenece; esta serie de ideas y valores nuevos que transfiere de manera oral, mediante una performance o representación, no necesariamente implica que sufra alguna forma de despersonalización. Justamente siguiendo al propio Slings, resulta imprescindible interpretar los textos dentro de su contexto para poder apuntar qué clase de yo, inclusive en cada ocasión, estaría afirmando el lírico. En un caso particular, por ejemplo Anacreonte,

${ }^{16}$ Ibid., p. 26.

${ }^{17}$ Ibid., p. 28. En cuanto al contexto, en sus conclusiones afirma: "I have already mentioned the growing importance of the symposium as a setting for the diffusion of lyric song, starting from the end of the seventh century. When people listen to poetry as members of a more or less formal group, they wanted to be addressed, exhorted, entertained as a group", p. 27. 
es posible pensar que no desaparece cuando compone y canta sus poemas frente al auditorio, precisamente porque es Anacreonte-como también Íbico y Píndaro- un invitado personal de los tiranos, no un aficionado con ciertas dotes. El poeta está consciente de que el acto de representación es un proceso, una obra que consiste en transformar el ‘texto’ en mensaje del autor al público, no sólo como comunicación a nivel lingüístico, sino como transmisión de emociones, pensamientos y visiones del mundo; el auditorio, a su vez, está suficientemente preparado para comprender la pluralidad de códigos que incluyen las diferentes esferas: la atención requerida, los niveles éticos, las formas de la comunicación misma y los referentes culturales, políticos y estéticos. Cuando se presenta una situación con tales características, este peso específico impide, o al menos dificulta, la idea de que el poeta se eclipse: es ya famoso y lo que debe decir, como tarea, ha de ser bueno y bello; me resulta difícil pensar en una máscara por completo desprovista de sello individual. Al contrario, tomando en cuenta todo lo anterior, hay que destacar cómo los líricos griegos procuraron decir lo que sentían y pensaban que alimentaría a su grupo -fuera una mera emoción personal, fuera el inicio de una axiología-, al desarrollar estrategias retóricas y métricas que se los permitieran.

Valga destacar una precisión que quizá no haya resultado suficientemente clara: no es con la filosofía como se adquiere la primera conciencia del yo, la autoconciencia, sino ciertamente con y por medio de la poesía como palabra creadora; ${ }^{18}$ no sólo se repiten los cantos

${ }^{18}$ La poesía precede a la filosofía; pero esto no implica devaluación alguna: "Si [sc. el hombre] abre la boca y dice bla, el hombre imita a Dios. Actúa como imitador cuando es fabril, productor, o sea poeta. Platón dice que todos somos poetas, que vale decir obreros. Añado que necesita palabras, para producir cualquier cosa material. Las palabras también son producto del obrero. Cuando ellas son sublimes, es decir, cuando no están al servicio de la producción fabril, ellas son palabras de poesía o de filosofía [...] Poesía es metáfora: transformación del mundo. Poesía es la salvación del alma, en este mundo transformable por el verbo [...] La poesía es más poderosa que la física y la astronomía, porque el arte poético transforma el mundo, mientras que la ciencia sólo lo representa. Por esto el científico no invoca los dioses y las musas cuando emprende su obra, como el poeta [...] Hacer poesía es sublime. Dar razón de la poesía es lo sublime de lo sublime. Cuando la filosofía se ocupa de 
antiguos, sino que se producen nuevos hallazgos morfológicos, formas desconocidas de establecer la concatenación y el ritmo de la suma de palabras hechas ideas, y plasmadas en un formato original que produce una musicalidad distinta a la que se genera en el ánimo del oyente con los hexámetros épicos. No se desprecia el pasado, sino se suma a la realidad presente, porque en este sentido la oralidad de la poesía, sea épica o lírica, sigue funcionando bajo un mismo fundamento pero con lenguajes diferentes, como si fuera una ignorada tonalidad de la luz:

También debe recordarse que, dentro de una dilatada sociedad oral, la función de la poesía no sólo es proporcionar entretenimiento estético, sino también servir virtualmente como el único medio de dicha sociedad para conservar y preservar la información necesaria [...] La poesía oral, con su canto y recitación rítmica, se convierte en el principal medio de educación y cohesión social. El objetivo del poeta lírico arcaico en Grecia no fue representar a su audiencia el desbordamiento espontáneo de poderosa emoción, recolectado en tranquilidad, sino proveer tanto de entretenimiento como de paradigmas de comportamiento personal, la

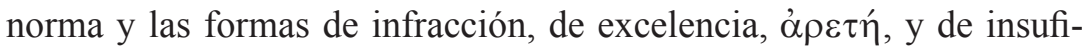
ciencia $[. .$.$] Su tarea fue, en resumen, la integración del individuo a la$ colectividad. ${ }^{19}$

Por esta razón, no es imposible pensar en la transmisión de un $\tilde{\eta} \theta$ os determinado a partir de una personalidad específica. La transmisión oral, que conservó tanto las gestas homéricas como los poemas de los líricos griegos, puede resultar algo difícil de asimilar en nuestros tiempos; las colecciones fueron compiladas hasta el período helenístico, hecho que fue posible gracias a la actividad de los aedos y rapsodas que todavía laboraban en los espacios privados y públicos, como reuniones, banquetes, certámenes y festividades; esto abre la puerta

ella, la poesía le transfiere su sublimidad, sin hacerle perder la suya", Eduardo Nicol, Formas de hablar sublimes. Poesía y filosofía, 1990, México, UNAM-IIFL, p. 10-28.

${ }^{19}$ Miller, op. cit., p. 5-6. Más adelante completa la idea: "the poem was inseparable from its performance. As with rapsodic, symposiastic, and cultic performances in archaic Greece, the text was less an artifact than an event", p. 8. 
a la suposición de que la lírica, como la entendemos actualmente, no nace con poetas como Safo, Alceo o Anacreonte, sino hasta el siglo I a. de C. en Roma. ${ }^{20}$ Lo anterior explica por qué poetas como Catulo o Tibulo, por ejemplo, no buscaban 'formar' a la sociedad ni exponer lo que consideraban el modelo o paradigma que debía ser seguido; la idea de lo individual aparece por primera ocasión sobre lo colectivo, desligado de una impronta ética, aunque vinculado todavía, de cierta manera, al contexto en que se produce. En cambio, la conciencia y autoconciencia del lírico arcaico no pueden configurarse cumplidamente si les falta la idea de pertenencia a una comunidad, y es esta idea de co-identidad o pertenencia a un grupo, a una sociedad, lo que permite establecer la hipótesis de que el poeta tiene una injerencia directa sobre el $\tilde{\eta} \theta$ os común que modelará, de manera paulatina, la conciencia general del hombre griego rumbo al siglo áureo de Grecia, aunque de su producción nos hayan llegado, desgraciadamente, sólo algunos hermosos reflejos:

Y con todo eso, los fragmentos componen una fuente deslumbrante de placer y de conocimiento, de conciencia, de dignidad, de estímulos del orgullo humano; sus temas fundamentales: la ciudad, el combate, el amor, la embriaguez del vino y el canto, acaso sean poderosos a explicar el terrible viento de juventud que la recorre y la anima.

El poeta, como hombre, se cumple básicamente por ser parte de la ciudad; sitio y raíz de solidaridad, la ciudad es ámbito de amor sensual y de la fraternal comunicación [...] Dentro de la ciudad [...] el poeta pretende las alegrías del amor; disfruta del vino y la poesía como bienes comunitarios. $^{21}$

Aunque poco nos haya llegado de sus obras, es innegable que la lírica griega arcaica fue parte no despreciable de las bases que configu-

20 "Hence, my contention will be that lyric, as most moderns think of it, does not begin with the archaic Greek lyrists [...] nor with the Hellenistic poets, but rather in the Roman period", Miller, ibid., p. 3.

${ }^{21}$ Antología de la Lírica Griega, 1988, México, UNAM, col. Nuestros clásicos 71, selección, prólogo, versión rítmica y notas de Rubén Bonifaz Nuño, p. 9. 
raron a la sociedad griega mediante un lenguaje (forma y contenido) creado para la transición: de la tiranía hacia la democracia; de la borrachera sin límite a la moderación y disfrute en el simposio; del modelo del héroe guerrero al del poeta que vive para y desde el amor; de la relación, por así llamarla, lejana, del hombre con los dioses a una cercanía más 'íntima' con algunas divinidades; $y$, en fin, del propio yo con el nosotros en el tiempo, conciencia primaria del carpe diem frente al silencio gris de la existencia en el Hades, profundo abismo. 